\title{
When Police Behave-A Transformation Program That Reshapes Police-Community Relationships Based on Problem Solving and Values
}

\author{
Mohamed Buheji \\ International Inspiration Economy Project- Bahrain \\ E-mail: buhejim@gmail.com
}

Received: April 19, 2020 Accepted: June 18, 2020 Online published: June 24, 2020

doi:10.5296/ijhrs.v10i3.17237ＵRL: https://doi.org/10.5296/ijhrs.v10i3.17237

\begin{abstract}
The escalation of the global events that followed the death of George Floyd in USA Minneapolis, Minnesota on May $25^{\text {th }}$ of 2020, and what followed from demonstrations in all over the world; despite the presence of a global pandemic, shows the importance and the complications of an event that started with police miss-behaviour. 'I can't breathe' a slogan carried by Floyd and many others earlier, carries within it, lots of meaning, however, one of the most important of meanings is the police brutality and the way they behave in certain times. This paper reviews the modern policing and specifically the values expected to be embedded in the police culture and the way they behave even in challenging times.

The literature review goes into exploiting the importance of police and community engagement through problem-solving programs and the accumulative collective impact on 'empathetic policing' that lead to 'social dialogue'. The case study in this paper focuses on the 'police inspiration labs' and how it gave a chance for more police with community engagement towards solving essential society problems. Besides, the paper shows the difference between (systems-driven vs behaviours-driven) police development programs. The paper carries important implication for developing further the role of the police in the 'quality of life' and support the government to transform the budget of policing into grey areas, i.e. area where the police are encouraged to execute more efforts towards preventing and developing instead of correcting and reacting towards community incidences and challenges.
\end{abstract}

Keywords: police behaviour, police values, community policing, police inspiration labs, police engagement, problem-solving, police development, police values 


\section{Introduction}

This paper explores the depth of police behaviour development programs as a result of the consequences of the events that started on May $25^{\text {th }}$ of 2020 by the death of George Floyd, a 46-year black man, died in Minneapolis, Minnesota after white police officer knelt on his neck while also two other officers straining him for almost nine minutes and Floyd shouting 'I can't breathe'. This incidence and all its behaviour were caught on camera in detail. The incidence as many see it is a consequence of events of police behaviour with black Americans specifically, while this paper considers that we need to see the incidence in the context of policing, police values and police training. Kindy and Brice-Saddler (2020).

All this started with a suspicion that Floyd might be using a counterfeit bill. The police claim that Floyd had resisted the arrest shows the opposite and the autopsies found Floyd's death to be a homicide. Floyd's death triggered demonstrations and protests in more than 75 U.S cities against police brutality, police racism, and lack of police accountability. Jacobs (2020). Floyd's death has been compared to that of Eric Garner, a black man who was killed in 2014 during an arrest for illicitly selling cigarettes, and many similar other failures to accommodate by engagement and value. Lots of debate started since then about defunding the police departments and sweeping police reform through legislations.

In this paper, we shall review and explore within the available scope of the paper the development of modern policing and the eras of police reforms and how this helped to redefine police role as we see it and experience it today. Then the researcher goes one step deeper to illustrate the mindset that controls the police behaviour. The capacity of community policing, including the development of the training programs to include more involvement with the Community, the hiring of minority police officers until the advent of creative policing, are reviewed.

The review goes into exploiting the importance of police-community involvement programs through problem-solving. How this engagement of the police brings an accumulative collective impact is also discussed in detail. The paper also shed light on the importance of empathetic policing in troubled communities, including the need for preparing for a time of 'social dialogue' instead of 'social instability'.

The author shares a case study for the 'police inspiration labs' and how it gave a chance for more police-community engagement towards solving essential society problems. Besides, the paper shows the difference between (systems-driven vs behaviours-driven) police development programs, taking a reminder of the development of the expectations of the generation today and the near future.

\section{Literature Review}

\subsection{Modern Policing}

The first modern police forces started in England in the first years of the

1600 's in the colonial era where police are appointed by governors and/or elected by the people to maintain order and provide other public safety services. By the early 1800's a major 
development happened with the purpose of crime prevention and control. The English police then were assigned the mission as paramilitary for preventive patrols and to support the protection of individual liberties. Schmerler et al. (2006).

England was also the pioneer of setting decentralised regional control of police agencies. The uniqueness of the English system is that its police stayed for a long time without the need to carry weapons in their patrol.

The police administration in England stayed also protected from political influence.

In the meantime, the USA policing got heavily involved with local politics and heavily armed. Modern Policing in the USA started in 1838. Local politicians used positions on the police force to reward their supporters. Since then, the police in the USA and many countries around the word started to be built based on ethnic and religious forces representing the local political influence. Kindy and Brice-Saddler (2020).

One could say that till the 1850's no well-structured community-based training program given to the police and the human capital system was unstructured, i.e. no transparency of the basis for recruitment, job security or retirement. Police work was inefficient, with no effective communication system and little supervision.

By 1830s the police were involved with the riots in several cities in the USA and U.K., mainly due to poor living conditions.

\subsection{Era of Police Reforms}

The civil unrest and the human rights movement in USA in the 1960s and early 1970's brought many police reforms, but most of these reforms focused on training and updating the police resources and technology. This type of reform, i.e. police training, resources, and system updating continued every time there are problems in the relation of the police with the minorities. Gabbatt (2020).

By the early 1980's the Community policing started. This is where the police started to get engaged for the first time in solving a community problem. Then, by the early 1990's the police became one of three measures or pillars of the quality of life of any community, where education and health are the other two measures, OJP (1997). Since then, the police were officially measured and even motivated to work closely, as partners, with the Community leading organisations and society leaders. Community policing started to spread to all developed countries and rich developing countries, Fischer-Stewart (2007). Here, we started to see innovation as 'neighbourhood watch', 'friends of the police', 'police performance ratings', etc. Also, we started to see at that time 'police-community relations councils' and citizens on patrol groups. Diamond and Weiss (2009), Sabath and Carter (2000).

Due to the new mindset that starts with community policing, community needs started to be one of the main inputs when police departments set their strategic plans. For example, depending on the type of the area or community main value-added competitive differentiation, you would see the type of patrol police. i.e. Hospitality or Tourism police, beach police, college police stations, etc. Friedell and Wycoff (2004), COPS (2002), Wasserman and Moor 
(1998).

With the 1990's we experienced a new trend in police best practices and entrance in excellence and total quality management programs which made get local and international awards. Police leadership, police strategy and police problems solving became more available and accessible to the public. Cohen (2001).

The spread of 'police substations' brought in new collaboration opportunities with community leaders and main community groups, Duffee et al. (2006). With this transformation, police started to be more worried about efficiency, and lost touch again with what started to be in the right path, i.e. to build effective communication with the public.

Since early 2000 we started to hear the same complaint about the police, i.e. despite having community policing, many members of the community experience difficulty in contacting the police in the right time, due to the bureaucratic system even with the small police stations. Elfrink et al. (2020), Diamond and Weiss (2009).

With the turn of the $21^{\text {st }}$ century social services to citizens became part of police routines, and the police replaced many municipalities work in different countries. The police inspection extended to the homeless, abused women, elderly homes, etc.

\subsection{Redefining Police Role}

With the development of their responsibilities, restructuring and redefinition of the role of police started. However, no real reforms were done in relevance to police behaviour with the public except through training and drill programs.

Police speed of response time to calls from community service became the most important measure for their performance. McCampbell (2010) reported how the redefinition of the role of the Baltimore (Maryland) Police Department (BPD) built a successful partnership with Chesapeake Habitat for Humanity $(\mathrm{CHH})$ to improve the public safety. This definition of the police role in the Community and the partnership collaboration helped to increase the community stabilization, expand the education for $\mathrm{CHH}$ homeowners, improve officer/community relations, enhance public safety and developed teamwork with the $\mathrm{CHH}$. Duffee et al. (2006), Sabath and Carter (2000).

\subsection{The Mindset That Controls Police Behaviour}

Studies show that the police patrol car serves to isolate the police officers from the Community as compared with police officers patrolled on foot, Wadman and Allison (2004). When police patrol on foot, they have the opportunity to engage with the Community and build a type of communication that leads to an appreciation of their challenges, McCampbell (2010). When police patrol by foot, or get engaged closely in conversations with a member of the public they have the opportunity to build more familiarity and even realisation overtime about the socio-economic issues of the neighbourhood which stimulate their empathetic thinking. ILJ (2005).

However, the mindset of the police is focusing on the service, and the rapid response rather 
than the depth of the engagement with the Community kept and alienated them from the public. This happens despite the recruitment of new mindsets that worked on developing the police behaviour. In many countries starting again in USA and U.K., and due to the social and political distrust between the minorities and the police, more police were recruited from the minority and the troubles communities themselves. However, again the outcome so far became poor. Kindy and Brice-Saddler (2020).

\subsection{The Capacity of Community Policing and Creativity}

With community policing, their engagement with society problem-solving started, POP Centre (2005). However, this relation stayed very basic with no depth in giving long term outcomes, since the focus was on solving day to day problems rather than the development of the Community. Gabbatt (2020), Diamond and Weiss (2009).

The Community policing meant to do policing prevention and control of minor crimes and disorders before they become serious crimes. This was reflected in police strategies. Through the philosophy of community policing, systemic partnerships and problem-solving techniques were developed. Cohen (2001), Schmerler et al. (2006).

Even though community policing get involved more today with the community issues as dealing with the management of crowds, dealing with abandoned houses, removal with junk cars, zoning dangerous areas, collaborating with community NGOs for public safety or festivals, there is no deeper engagement for effective correction of practices, or development of community issues. Fischer-Stewart (2007), Duffee et al. (2006).

Today, police more than ever encouraged to be creative in responding to community problems. The creativity of the policing comes from their capacity to bring in the Community to be a full partner in preventing and responding to security and safety problems. McCampbell (2010).

\subsection{Community Involvement in the New Normal}

The Community provides their police agency with invaluable information on both the problems of concern to them and the nature of those problems. Community involvement also helps the police to ensure that the community insights and perspectives are included. The collaboration and focused efforts in community-related efforts raise the capacity of seeing opportunities in the problem and determining the extent of outcome that could be achieved. Cohen (2001).

There are good success stories about the results of a partnership between the police and the Community which led to a more systematic, comprehensive approach to addressing the increase in crimes and disorder, or prevention of social tensions, or organisation of regional or global events, or development of common good initiatives, or recognition of the quality of life achievements, OJP (1997).

The more police found to be involved closely with community problems the more the police officers would be involved in solving the problems from its roots and became more believers in interactive partnerships with the community stakeholders, thus gain more public trust. 
McCampbell (2010).

As we enter the new normal, post-COVID-19 era, new risks and as well as identifying new access means and resources. In this era of new normal trust would be the main element of the journey. Many relations would need to be reassessed to determine what suite the new age we entering in. Sabath and Carter (2000).

In this 'new normal', police to need to deeply assess what is working and what is not working in relevance to building and sustaining relations with the Community and to making them an integral part of the process of quality of life development. Hence, the first thing police should do in the new normal is reviewing the 'communication model' with the Community. OJP (1997).

\subsection{Expanding the Police Collective Impact}

To create a collective impact, the police need to get involved with other police and the members of the Community on common good projects that bring in long term realized change. Such projects are the best type of training that change the assumptions, the attitudes, the behaviours, the reflection of the police officers and brings them to a common understanding with the Community.

Once the police on the field trying to solve the problem rather than report a problem or react to it, they would start to appreciate the tools and would identify the most suitable competencies that would alleviate or eliminate the risks. Cohen (2001)

Since R = P (Availability), police started to use Geographic Information Systems (GIS) as a source for reliable data that can increase their availability at the right time and place. The GIS was used first by the police for crime tracking, and the application widens to include community-policing. Through GIS community could allocate where the dangers or risks are, what nature offenders are, the precise information of the area. Buheji et al. (2018a), Schmerler et al. (2006).

\subsection{Empathetic Policing in Troubled Communities}

Empathetic policing, i.e. when the police put themselves as if they are the members of the troubled Community, they can bring more realistic solutions. To bring this 'empathetic thinking', the police need to collaborate and work with community groups on development and problem-solving PSPS projects and not only in social support services.

The extensive involvement in community projects brings in more understanding of the social issues that underlie the surface of what is seen as a crime. Buheji (2019b)

Through the capacity to apply empathetic thinking, many of the disadvantaged people needs can be discovered. This builds a stage of profound knowledge that make the police compassionate about the need for change.

In many occasions, established empathetic policing brought much development to the long term local community and national security infrastructure while also addressing human needs. 
2.9 Preparing for Time of 'Social Dialogue' Instead of 'Social Instability.'

The COVID-19 pandemic has exposed many social issues that were sinking without been noticed or resolved; social inequality is just one of them. The number of vulnerable people to the socio-economic crisis has increased dramatically, due to the COVID-19 spillovers.

In this unprecedented time, we need to open projects that bring synergy and open, direct and indirect, social dialogue that helps to heal the Community from the political, economic, social, technical and legal challenges that are rapidly folding; due to the consequences of the new normal.

This start with taking inventory of what is the depth of the problem during the COVID-19 and then understanding the strengths and the limitations of the solutions that this problem could bring. The Community need to realise that the social dialogue is helping to develop a scenario about why the problem is occurring and then see that this is helping to narrow the scope of the problem and identifying the different type of resources that may be needed.

\subsection{Police-Community Problem Solving Program}

\subsubsection{Importance of PSPS Programs}

Police community problem solving (PSPS) program is a program that focuses on totally engaging the participating police officers with the roots of a specific community problem and make them the leading experts in solving it with a clear outcome. PSPS programs can come in different approaches, but they are meant to bring the police closer to the Community and vice versa. This clear outcome should be reflected in the amount of improvement of the quality of life indicators that happened in the Community, directly or indirectly. Buheji (2019b), POP Centre (2005).

One of the best practices would include the reduction of crimes, due for example, to the collaborative efforts with the 'neighbourhood watch program' in the Community, ILJ (2005). Another outcome might reduction of drug and drug addicts in schools due to the collaboration between the entire stakeholder the local police, the parents, and the teachers in the school, besides the students' leaders. Duffee et al. (2006).

PSPS program thus promotes a sense of community ownership of the problem, and motivate the different leaders in the Community to set the proper environment that would exploit the optimum opportunities for the targeted outcomes. PSPS program help to maintain and strengthen the relations between the stakeholders and bring amongst them synergy. Repetition of projects brings shared vision and common goals for the collaboration, knowledge-sharing, and capacity building. Sabath and Carter (2000).

\subsubsection{Community Engagement in Solving Safety Problems}

The police need to collect the most suitable data about the targeted community problem, both quantitatively and qualitatively. The key to effective problem solving is the use of a structured process known as to use the SARA methodology which a short for the following: Scanning, Analysing, Responding, and then Assessing. However, in outcome-driven projects 
the police are advised to use $R A D A R$ which means: focusing the outcome Results, setting the right Approach, then Deploying the project and the Action plans, the assessing and Reviewing again.

\subsection{2.a Scanning of the Community Problem to Explore Opportunities not Only Solutions}

In this stage, the police identify and observe the recurring problems of concern to the public and the police and understand not only the consequences of the problem for the Community, but the opportunities inside this problem. The police based on the: Depth of the Problem (its frequency) + consequence of the problem occurrence (the hazard) + the opportunities inside the problem, can make the decision to prioritize the specific problem to be taken as a project. Then deeper data need to collect in the that specifically identified part of the problem to solve. Cohen (2001).

\subsection{2.b Analysing the Selected Community Problem}

Once the general data are collected both qualitative and quantitative analysis need to be done to understand and absorb the conditions of the events

\subsection{2.c Responding to the Selected Community Change}

Based on the field analysis interventions action plans are deployed. During the process of deployment, other communities with similar problems are integrated into the solution process. Alternative interventions would be field-tested in small boundaries. These interventions would link the specific objectives with the response plans.

\subsection{2.d Assessment to the Executed Change}

As the project is implemented, both the situation before and after response are compared. Since the target is to change the police behaviour, the focus should be on the extent of outcome achieved and what type of capacity raised with minimum resources, and not the results did. i.e. the concern will not be the establishment of the system, but the emphasis on critical outcome indicators in relevance to safety and security prevention or reaction to the Community, Friedell and Wycoff, (2004). Determining whether outcome goals are achieved should be a concern to the police team since this would ensure the change of their mindset development and the commitment for future projects; however, even failures to achieved the targeted outcome would be considered as part of the achievement.

\subsection{Comparison of Police Development Program (Systems-Driven vs Behaviours-Driven)}

There are hundreds of police programs that were initiated by the police and the policymakers to improve the response, the agility and the effectiveness of the police and policing services. To mention some of the most important developments in the last one century could mention the following: the Radio \& T.V. Awareness Policing, Strategic and Scenario Planning Policing, Police Call Centres, the Quality Management Systems Police, the Efficient Police, the Specialised Patrol Units Policing (Tourism Police, Drug Prevention Police, Family Police, Safe Schools Police, Sea Beach Police, Horse Patrol Police, Dog Police, Bicycle Police, Internet Policing, Child Abuse Police, Women Protection Police, etc.). Wadman and Allison 
(2004).

In the last half-century, we noticed the following programs that are meant to develop the police even further through the Predictive Policing, the Civilian Police, the Community Police, TQM Police, Benchmarking Police, Excellence Awards Police, Knowledge Management Police, Mobile Police Stations, Environmental Friendly Police, Digital Observatory Police, Future Foresight Police, Smart Policing, Innovation Policing, A.I. Policing, Data Mining Police Units, Virtual Police Stations, and e-Services Police. Fischer-Stewart, (2007) COPS (2002)

If you notice from all the mentioned development programs which one might notice in his/her country or Community, they are meant to develop the system at most, only less of them, about 20\%, would have managed to develop the police behaviour; and only if they were implemented honestly, effectively and sustainably. Yes, these programs have addressed or managed to meet many of the expectations of the public, but system-wise only. i.e. The gap continued to grow between what the police are trained for and prepared to respond to or deal with and/or react to, and the expectation of the communities over the last 130 years.

\subsection{Era's of Police Development vs Generations Expectations}

\subsubsection{Understanding the Basis of Police Development Over the Last one Century}

If we review the last 130 years, i.e. since the early 1890's till 2020 will notice that the police have come a long way in the quality and sophistication of its services of response delivery, these one century plus years can be divided into mainly three era's to show the differentiation of what happened to the different generations in relevance to systems and behaviour. Due to the conditions of the world and the human civilisation the different eleven to twelve generations that came from 1918 and on gone through three different era's that controlled the mindset of the Community and defined its expectation to the services delivered by the police. The three era's that we shall discuss here is the era of empowering corporations, the era of empowering people, and lately the era of value-driven life. The details of these eras are reflected in Table (1). Gordon (2003).

\subsubsection{The Era of Empowering Corporations}

This era which started from 1890 till 1964, i.e. more than half a century, focused on creating scalable efficiency in the human productivity through systems that emphasised mainly 'Doing things Right' instead of 'Doing the Right thing'. The causality for that might be due to the world have just finished its three main crisis two world wars WWI (1914-1916), and WWII (1939-1945); where many people militarized, millions died or worked on factors or corporates that dealt with them as part of the system, i.e. like machines. This, besides the world, managed to lose hundreds of thousands due to the major pandemic or the Spanish flu, between (1918-1919).

In the empowering corporations' era, the police managed to develop its basic systems and departments, besides its early equipment that improved the efficiency and speed of response to accidents or incidents. The value of the police was to be more organised, confidential and 
deliver similar work in different places and time if the conditions are the same, Wasserman and Moor (1998). The training and shaping of a police officer stayed to be focused on how to deal with the public where the police are expected to eliminate the troubles in the most efficient way, which they perceive that the members of the community start. Gordon (2003).

\subsubsection{The Era of Empowering People}

In this era which lasted on 20 years, i.e. (1975-1994) the focus was on scalable adaptability, i.e. 'Doing the Right Things', which is beyond 'Doing things Right'.

This is the era where the police had the change to adapt to the speed of change happening the urban and rural communities. The era where there were lots of socio-economic projects coming in most of developed and leading developing countries, however, the police stayed focused on the same routine and type of training and development of some drills techniques that the newly acquired technology as the telecommunication system support. The mindset of seeing the Community as a receiver of the service and not as a stakeholder kept the game on the concept of the 'hide and seek'. The police try to catch people in making mistakes instead of working with people and communities to prevent accidents or learn from it. The Community move to a higher mindset where the focus and the values are on first selecting the right thing, while the police stayed focused on doing thing right, and the training stayed the same.

\subsubsection{The Era of Life Values}

In this era which is estimated to stay, as per the author research and publications, till 2030, i.e. 30 years in total, we started to witness the focus on scalable agility. The trend of this $\mathrm{Z}$ and Alpha focused generation on creating a change; therefore, they call them the 'Me generation'. They are a generation that grown on believing in 'Optimising Values-driven Opportunities'. i.e. value for them is the top thing on the agenda. Whatever this value is. Gordon (2003).

However, and despite this huge jump in values, the police stayed focused on developing its services, its systems, and infrastructure; besides its training and recruitment schemes. The values stayed maturing slowly compared to a generation and surely communities that see values and engagement is the measure and the indicator for the effectiveness and transparency of any entity. Wasserman and Moor (1998). 
Table (1). The Main Era's and Generations that Police dealt within the last 130 years

\begin{tabular}{|c|l|l|l|}
\hline Type of Era & \multicolumn{1}{|c|}{ Generation Name } & $\begin{array}{c}\text { Births } \\
\text { Start }\end{array}$ & $\begin{array}{c}\text { Births } \\
\text { End }\end{array}$ \\
\hline \multirow{2}{*}{$\begin{array}{c}\text { Era of Empowering } \\
\text { Corporations } \\
\text { (Scalable Efficiency) } \\
\text { Doing things Right }\end{array}$} & Lost Generation & 1890 & 1915 \\
\cline { 2 - 4 } & Interbellum Generation & 1901 & 1913 \\
\cline { 2 - 4 } & Silent Generation & 1925 & 1945 \\
\cline { 2 - 4 } & Baby Boomer Generation & 1946 & 1964 \\
\cline { 2 - 4 } & Generation X & 1965 & 1979 \\
\hline \multirow{2}{*}{$\begin{array}{c}\text { Era of Empowering People } \\
\text { (Scalable Adaptability) } \\
\text { Doing the Right Things }\end{array}$} & Xennials Generation & 1975 & 1985 \\
\cline { 2 - 4 } $\begin{array}{c}\text { Era of Life Values } \\
\text { (Scalable Agility) }\end{array}$ & Y Generation-"The Millennials" & 1980 & 1994 \\
\hline $\begin{array}{c}\text { Optimising Values-driven } \\
\text { Opportunities }\end{array}$ & Z Generation & 1995 & 2012 \\
\cline { 2 - 4 } & Alpha Generation & 2013 & 2025 \\
\cline { 2 - 4 } & Post-Corona Generation & 2020 & 2025 \\
\cline { 2 - 4 } & Generation X2 & 2025 & 2030 \\
\hline
\end{tabular}

\section{Methodology}

This paper focuses on what might trigger the change in police forces and officers behaviour to be more values-driven and in coherence with the community needs. The author reviews through different projects carried out in the case study a list of fourteen 'inspiration labs' done in some of the GCC countries. The goal of these labs is to create a change through the engagement of the police officers with both the members of the Community and the stakeholders of the project. These 'inspiration labs' managed to build up a new mindset for the police officers who participated in such programs, from 2015 till 2019. Buheji (2018).

Such police officers engagement programs or labs are summarised through a framework proposed for establishing empathetic value-driven police that would behave according to community expectation and who can help to build trust in the police system and culture.

\section{Case Study}

\subsection{Inspiring Police and the Community Through Inspiration Labs}

The Community could get inspired by the police if they got engaged together through projects that add value and solve chronic social problems. The projects could also prevent accidents and incident. The partnership between the police and the Community would be more realised, the more both see the outcome of their work.

The police inspiration labs that were carried out since 2015 in different Gulf Cooperation Council focused on improving the Community's quality of life brought more police officers nearer to the Community and established a unique type of trust. Buheji (2018), OJP (1997).

The police inspiration labs helped to tackle the challenging issues as repeated cases of 
jewellery robberies in specific Bazar neighbourhood, or finding common ground for disputes within neighbours over, for example, double parking issues, etc. The uniqueness again is that such projects were carried through the engagement of community and stakeholders' representatives. ILJ (2005).

The outcome of fourteen projects given as a sample from the 'police inspiration labs' shows that working together with the Community on solving problems helped to make the police officer find the 'common ground' easily. The labs gave the police officers the time to use and practice both their 'fast and slow thinking', as they have managed to discuss and explore together with the stakeholders the opportunities inside each problem, in none fault-finding environment.

The analysis of the previous labs shows that the behaviour of those police who practicipated in the program effectively started to change positively. Clearly, those dedicated participants showed a clear paradigm shift in the meaning of policing to them. The police officers started to see and filter the common grounds of 'where and what could be agreed' with their community or when they interact with an incidence. National Research Council (2004).

\subsection{Balancing the Perception and the Way the Police Behave}

The six-months 'police inspiration labs' helped to build teamwork spirit between the police and the Community. The labs projects brought lots of balance to the mindset of almost all the participating police officers who joined the program over the four cohorts that had a total of 90 graduated officers. Many officers saw that their way in interaction with certain issues in the Community were wrong and inaccurate and their myths, or assumptions were shaken after they collected, analysed and synthesised facts. Due to the change in mindset and behaviour, their approach to solving community problems changed dramatically. National Research Council (2004).

The focus on achieving outcomes from the projects that influence the quality of life of the Community and the stakeholder, rather than just results also played a role in reducing many strained relations between the police and critics of the huge police budget. Elfrink et al. (2020). OJP (1997).

\subsection{Re-establishing the Communication and Trust Model between the Police Officers and the Community}

The 'police inspiration labs' managed to re-build the trust with the Community. This trust found to be central to developing any collaborative relationship and effective, empathetic based problem-solving outcomes. The labs gave the participating police officers the chance to build this trusting relationship with maturity as they navigated their way towards creating change and sustaining change in the Community. Buheji (2018b)

The trust also brought many ideas of other projects in relevant to preventive policing. Besides, the 'police inspiration labs' embedded the spirit of 'learning by doing', 'learning by exploring', 'research and development' in the mind of the participating police officers. All the participating officers became well trained in differentiating between moving and reacting 
based on facts and clear evidence and reacting based on opinion and noisy information. Buheji (2018)

\subsection{Sample of 'Police Inspiration Labs' and Their Influence on Mindset Specific Values and Behaviours}

In the following Table (2) some of the 'police inspiration labs' are listed in Buheji (2018b) and are linked to the type of values that are experienced by the author and which have a fold on the way the police positively behave.

Table (2) Type of 'Police Inspiration Labs' vs Values Gained from each Project

\begin{tabular}{|l|}
\hline Type of Police Inspiring Projects \\
\hline $\begin{array}{l}\text { 1-Reduction of gold and jewellery theft from gold market shops } \\
\text { through Collaboration between Jewellery Shops Owners }\end{array}$ \\
\hline $\begin{array}{l}\text { 2-Ease of flow from main points of entry at both airport and } \\
\text { ports without an increase in resources or negligence of safety } \\
\text { and security + Improving airport immigration officers' services } \\
\text { (restore competitiveness spirit). }\end{array}$ \\
\hline
\end{tabular}
(restore competitiveness spirit).

3-Enhance social harmony between neighbors due to parking or similar small issues

4-Improving mobile and patrol policing effect and efficiency, especially in disserted areas.

5-Reduction of cases transferred to court due to family and marriage disagreements by solving it at first instance in the police station.

6-Improving the outcome of creating "Self-Dependent" youth in the 'Police Youth Summer Camps' which is held for three weeks.

7-Reducing police turnover-ratio in leaving specific critical units as guarding or working for jail rehabilitation units due to difficult and psychologically stress jobs.

8-Raising Safety Readiness and Evacuation of residential and commercial buildings (Civil Defense).

9-Reducing causes for illegal labour crime.

\section{Type Value Learned}

-Collaborative and Safe Neighborhoods

-Empathetic Policing

-Customer Service

-Collaborative and Safe Neighborhoods

-Safety Prevention -Preventive Policing -Family Stability

-Community Development

-Quality of Life

-Creating Ownership in Health \& Safety

-Safety Prevention -Safety Neighborhoods 


\begin{tabular}{|l|l|}
\hline Type of Police Inspiring Projects & Type Value Learned \\
\hline $\begin{array}{l}\text { 10-Strengthening the social role of the police (the relationship } \\
\text { between police stations and community centres). }\end{array}$ & -Community Development \\
\hline $\begin{array}{l}\text { 11-Raising learning and knowledge management in (Economic } \\
\text { Crimes). }\end{array}$ & -Preventive Policing \\
\hline $\begin{array}{l}\text { 12-Enhancing social security by promoting prevention in the } \\
\text { social tranquillity schemes. }\end{array}$ & -Community Resilience \\
\hline $\begin{array}{l}\text { 13-Raise confidence through enhanced quality (traffic service) } \\
\text { (minimise violation vs. improve drivers self-alert tools) }\end{array}$ & $\begin{array}{l}\text {-Ownership of Safety } \\
\text { Responsibility }\end{array}$ \\
\hline $\begin{array}{l}\text { 14-Improve the follow-up service of the communication with } \\
\text { the stakeholder in police stations. }\end{array}$ & -Community Engagement \\
\hline &
\end{tabular}

\subsection{Applying a Sample of 'Police Inspiration Labs' and Its Influence on Police Behaviours}

In order to exemplify how the tackling a community problem through engaging the Community with the police, we will take the first case in Table (2) and study the problem vectors, i.e. the opportunities that if tackled would help to bring the targeted outcome as per Buheji (2018a).

The outcome targeted in case- 1 is focused on eliminating or reducing the jewellery thefts in the gold market. Thus, through applying one of the 'inspiration labs' tools, as per Buheji and Ahmed (2019), and which is called 'differential diagnosis' the three problem vectors identified in this case are as shown in Figure (1):

1- Applying the protocols of community policing inspection and assessment for the readiness and fitness of the jewellery shops. i.e. evaluate anti-theft procedures for each shop and in the market in total. Targeted Value: Safe Neighbourhood-Policing.

2- Emphasising 'Incident Management System' in all jewellery shops. i.e. register of near miss cases where theft or loss of jewellery could have happened due to failure to follow the procedure, or due to problem in the procedure. Targeted Value: Safe Neighbourhood-Policing.

3- Establish collaborative community prevention project, i.e. similar to inspiration labs. Targeted Value: Collaborative Policing.

Figure (1) Example of a 'Police Inspiration Lab' and How Values Correlated to Problem Vectors are Identified. 


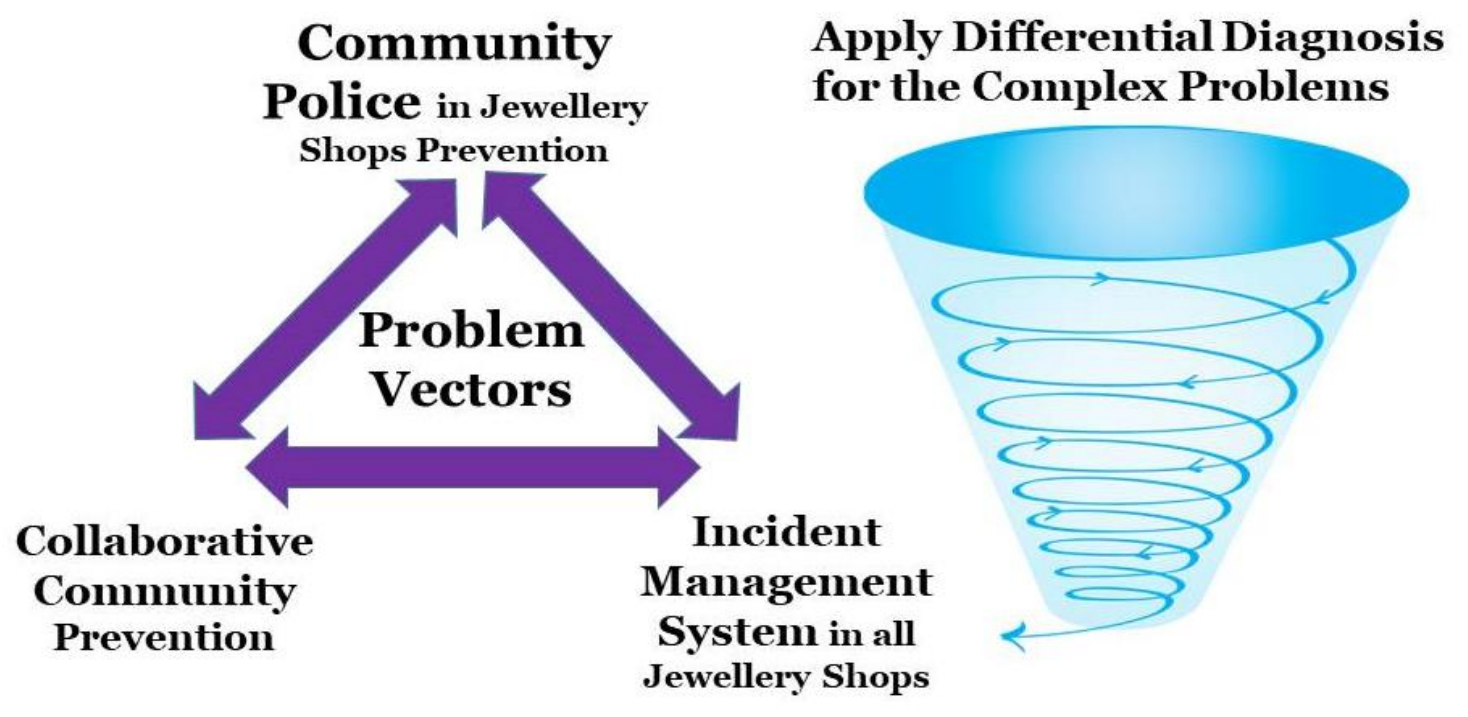

\section{Discussion}

\subsection{When Police Behave}

The case shows that police can behave with a high level of integrity, empathy and collaborative spirit always remembering they are members of the Community when they are given enough time to get engaged with community development focused projects, similar to the 'police inspiration labs' projects. Having the police officers given enough time to work on 'a common good project' improve the way they behave since their mindset would shift from 'what is happening from the community', to 'what can happen from me to the community'. Buheji (2018b).

Such engagement programs if they got the support of the government could help to control the budget of the police given for 'reactive policing' and make it more towards 'preventive policing'. This would help to reduce many Community disputed budgets and would create a grey area that encourages the police to execute more efforts on prevention and development instead of correction or reaction.

\subsection{Producing Tangible Outcomes}

When police, along with the Community produce tangible outcomes, they start realising the importance of collaborating and building positive relationships among the community members through projects.

The sole training of the police without being engaged with the Community in full program complicates matters for the police officers with the public once they need a deal with a variety of issues. Educating partners about the operation and realities of the police through 'learning by exploring' can also build more respect and trust to the police officers.

Tangible outcomes, or even the failures to achieve from first attempt help to generate a type of excitement and increase the likelihood of even further police-community involvement.

The community member would agree to be more engaged and take responsibility for 
preventive policing, which again would bring more sustainability and reliability for the projects.

\subsection{Stopping What Trigger Negative Police Behaviour}

When police officers build real commitment to solving specific community problem, they are actually building passion, which consists of persistence and perseverance to tackle the community challenges from a different approach. Besides, such engagements with the community helps to build respect and trust between the police and the society stakeholders. Just the fact that the police officers can have the capacity to keep the Community focused on solving problems, means they are activating preventive policing more and more.

\section{Recommendation and Conclusion}

\subsection{Recommendation of the Paper}

Investing in police engagement with the Community and socio-economic development projects considered one of the main under-mind techniques in many police till date. There is now well-established evidence that such engagement-driven projects build trust and emphasis more 'preventive policing'. This is highly needed in troubled, unstable communities where poverty, racism, social tensions are clear.

Projects similar to 'police inspiration labs' can help to develop an effective 'communication model' between the police and their Community. Such programs bring in a variety of visible and hidden opportunities for the police and their reputation, besides improve the way they behave during crisis or emergencies.

\subsection{Implications and Limitation of This Paper}

The paper did not specify what types of police behaviour needed to build specific coherence with the Community, since this depends on the type of conditions and time. Community stakeholders' engagement gives more chance for the police to build collaborative behaviour, while also solving problems that would improve the outcome of preventive and community policing. This means those police training academies should budget for labs or projects that sharpen the police officers to be more community-friendly and to behave positively to the challenges uprising,

The implications of this study is that it would bring in more Community policing initiatives and would help to reduce the disputed budgets for police training and drill that focus just on police reactions to community problems rather than prevention. The other implication of implementing this paper proposed labs is that more bridges of trusts could be built especially in an unstable environment or communities. Building such programs within the culture of the police would give them a new source of behaving that is based on joint decision making and collaborative actions to deal with community challenges.

Due to the limitations of the scope of the paper, the details of the 'police inspiration labs' as the communication model, the way the projects are organized, the way the observations are collected, were not covered explicitly. 


\section{Macrothink}

International Journal of Human Resource Studies

ISSN 2162-3058 2020, Vol. 10, No. 3

Finally, one has to appreciate that policing is one of the most important jobs, yet it is also a stressful job that has not been given empathetic thinking training and development. The police need motivations that make them realise that the members of the Community appreciate them; this can come main by project design that is based on engagement and the development of the mindset.

\section{References}

Buheji, M. (2019a). Understanding the Economics of Problem-Solving. A Longitudinal Review of the Economic Influence of Inspiration Labs- Three Years Journey on Socio-Economic Solutions. American Journal of Economics, 9(2), 79-85

Buheji, M. (2019b) Shaping the Anatomy of Socio-Economic Community Problems towards Effective Solutions. Issues in Social Science, 7(1), 1-11.

Buheji, M., \& Ahmed, D (2019) The Defiance - A Socio-Economic Problem Solving, AuthorHouse, UK.

Buheji, M. (2018a). Re-Inventing Our Lives, A Handbook for Socio-Economic "Problem-Solving", AuthorHouse, U.K.

Buheji, M (2018b) Empathetic Engineering in Inspiration Leadership Program, Case Studies on Happiness Creation in Public Policing Services, 47th IFTDO World Conference \& Exhibition FUTURE IS TODAY | CREATING HAPPINESS AT WORKPLACE, 20-22 March 2018, Dubai, UAE.

Cohen, D. (2001). Problem-Solving Partnerships: Including the Community for a Change. Washington, DC: Office of Community Oriented Policing Services, U.S. Department of Justice. Available at: http://www. cops.usdoj.gov/ric/ResourceDetail.aspx?RID=163., Accessed on: 1/6/2020

COPS (2002). COPS Innovations: Promising Strategies from the Field (A National Overview). Washington, DC: Office of Community Oriented Policing Services, U.S. Department of Justice. Available at: http://www.cops.usdoj.gov/RIC/ResourceDetail. aspx?RIF=513., Accessed on: 1/6/2020

Diamond, D., \& Weiss, D (2009) Advancing Community Policing Through Community Governance: A Framework Document. Washington, DC: Office of Community Oriented Policing Services, U.S. Department of Justice. www. cops.usdoj.gov/RIC/ResourceDetail.aspx?RID=521., Accessed on: 1/6/2020

Duffee, D., Renauer, B, Scott, J., Chermak, S., \& McGarrell, E. (2006) Community Building Measures: How Police and Neighborhood Groups Can Measure Their Collaboration. Washington, DC: U.S. Department of Justice. www. ncjrs.gov/pdffiles1/nij/grants/213134.pdf., Accessed on: 1/6/2020

Elfrink, T., Bella, T., Shepherd, K., Chiu, A., Flynn, M., Wagner, J., \& Mettler, K. (2020) George Floyd live updates: Congress to debate sweeping police reforms as Derek Chauvin appears in court. June

8 
https://www.washingtonpost.com/nation/2020/06/08/george-floyd-protests-memorial-updates /

Fischer-Stewart, G. (2007) Community Policing Explained: A Guide for Local Governments. Washington, DC: Office of Community Oriented Policing Services, U.S. Department of Justice. Available at: http://www.cops.usdoj.gov/RIC/ResourceDetail.aspx?RID=430., Accessed on: 1/6/2020

Friedell, L., \& Wycoff, M (2004) Community Policing, The Past, The Present, and Future. Washington, DC: Police Executive Research Forum. Available at: www.policeforum.org/upload/CommunityPolicingReduced_570119206_12292005152352.pd f., Accessed on: 1/6/2020

Gordon, M. (2003). Making the Match: Law Enforcement, the Faith Community and the Value-Based Initiative. Washington, DC: Office of Community Oriented Policing Services, U.S. Department of Justice. http://www.cops.usdoj.gov/ric/ResourceDetail.aspx?RID=137. , Accessed on: 1/6/2020

Gabbatt, A. (2020). Protests about police brutality are met with wave of police brutality across U.S., The Gaurdian. https://www.theguardian.com/us-news/2020/jun/06/police-violence-protests-us-george-floyd. Accessed on: 6/6/2020

ILJ. (2005). Engaging the Community in Project Safe Neighborhoods. Institute for Law and Justice, Washington, DC: U.S. Department of Justice. http://www.psn.gov/ pubs/pdf/PSN_CE_Monograph_FINAL.pdf., Accessed on: 1/6/2020

Jacobs, S (2020). NYPD faces 633 complaints after a week of protests., June 6, https://www.washingtonpost.com/national-security/george-floyd-protests-new-york-nypd-co mplaints/2020/06/05/dd91e4dc-a754-11ea-b619-3f9133bbb482_story.html

Kindy, K., \& Brice-Saddler, M. (2020). Experts doubt this is a moment of reckoning for policing in U.S. June, 8 https://www.washingtonpost.com/ ,

McCampbell, M. (2010). The Collaboration Toolkit for Community Organizations: Effective Strategies to Partner with Law Enforcement,

MetLife Foundation. (2008). MetLife Foundation Community-Police Award Winner, Orchard Gardens/Commons Public Safety Committee. New York: Local Initiatives Support Corporation. www.lisc.org/content/publications/detail/17643., Accessed on: 1/6/2020

National Research Council. (2004). Fairness and Effectiveness in Policing: The Evidence, Chapter: 5 Explaining Police Behavior: Organizations and Context, https://www.nap.edu/read/10419/chapter/6\#112, Accessed on: 1/6/2020

OJP (1997). Community Strategies for Improving the Quality of Life. Washington, DC: Executive Office of Weed and Seed Programs, U.S. Department of Justice. http:// www.ojp.usdoj.gov/ccdo/pub/pdf/qolmas.pdf. , Accessed on: 1/6/2020 


\section{Macrothink}

International Journal of Human Resource Studies

ISSN 2162-3058 2020, Vol. 10, No. 3

Sabath, M., \& Carter, H. (2000) Evaluation of Efforts to Strengthen Police-Resident Relations in El Centro, California: A Final Report. Washington, DC: U.S. Department of Justice. http://www.ncjrs.gov/pdffiles1/nij/grants/181051.pdf., Accessed on: 1/6/2020

Schmerler, K., Perkins, M., Phillips, S., Rinehart, T., \& Townsend, M. (2006) A Guide to Reducing Crime and Disorder Through Problem-Solving Partnerships. Washington, DC: Office of Community Oriented Policing Services, U.S. Department of Justice. www.cops.usdoj.gov/ric/ResourceDetail. aspx?RID=164. , Accessed on: 1/6/2020

POP Centre (2005) History of problem-oriented policing. Center for Problem Oriented Policing, www.popcenter.org/about/?p=history. Accessed on: 1/6/2020

Wadman, R., \& Allison, W. (2004). To Protect and Serve: A History of Police in America. Upper Saddle River, NJ: Prentice Hall.

Wasserman, R., \& Moor, M. (1998) Values in Policing By Perspectives in Policing, John F. Kennedy School of Government, Harvard University, November.

\section{Copyright Disclaimer}

Copyright for this article is retained by the author(s), with first publication rights granted to the journal.

This is an open-access article distributed under the terms and conditions of the Creative Commons Attribution license (http://creativecommons.org/licenses/by/4.0/). 